\title{
Beyond lung function in COPD management: effectiveness of LABA/LAMA combination therapy on patient-centred outcomes
}

\author{
*Thys van der Molena, Mario Cazzola \\ a Department of General Practice, University M edical Center Groningen, Groningen, The Netherlands \\ ${ }^{\mathrm{b}}$ M edicina Interna, Università di Roma Tor Vergata, Rome, Italy
}

Received 15th June 2011; revised 26th August 2011; accepted 9th September 2011; online 5th January 2012

\begin{abstract}
Bronchodilators are central to the management of chronic obstructive pulmonary disease (COPD). Clinical studies combining different classes of bronchodilators, in particular a long-acting muscarinic antagonist (LAMA) and a long-acting $\beta_{2}$-agonist (LABA), have demonstrated greater improvements in lung function (forced expiratory volume in 1 second, FEV 1 ) in patients with COPD than monotherapy. FEV 1 has served as an important diagnostic measurement of COPD, and the majority of clinical studies of currently available pharmacotherapies grade effectiveness of treatment regimens based on improvements in FEV 1 . However, FEV 1 alone may not adequately reflect the overall health status of the patient. Published evidence suggests that LABA/LAMA combination therapies demonstrate greater improvements in patient-centred outcomes such as dyspnoea, symptoms, rescue medication use, and quality of life than individual drugs used alone. Evaluating patient-centred outcomes associated with COPD is likely to play an important role in future research as a measure of overall treatment effectiveness. Raising awareness of the importance of outcomes beyond lung function alone, particularly in primary care where most patients initially present themselves for medical evaluation, should form a fundamental part of a more holistic approach to COPD management.

(C) 2012 Primary Care Respiratory Society UK. All rights reserved.

T van der Molen and M Cazzola. Prim Care Respir J 2012; 21(1): 101-108

http://dx.doi.org/10.4104/pcrj.2011.00102
\end{abstract}

Keyw ords COPD, bronchodilators, combination therapy, long-acting muscarinic antagonists, long-acting $\beta 2$-agonists, patient-centred outcomes

\section{Introduction}

Bronchodilators are the cornerstone of pharmacological management of chronic obstructive pulmonary disease (COPD), and current guidelines recommend their use as first-line therapy in symptomatic patients with airflow limitation. ${ }^{1,2}$

Short-acting bronchodilators are typically used for immediate relief of symptoms, with long-acting agents being preferred as maintenance therapy to prevent or reduce symptoms. ${ }^{3,4}$

For patients whose symptoms are not sufficiently controlled by maintenance monotherapy, the combined use of bronchodilators of different classes - in particular an inhaled muscarinic antagonist and a $\beta_{2}$-agonist - is a favoured strategy for maximising bronchodilation in COPD. ${ }^{1}$ Using this combined approach, bronchodilation is obtained both directly, through stimulation of $\beta_{2}$-adrenergic receptors using $\beta_{2}$-agonists, and indirectly, by inhibiting the action of acetylcholine at muscarinic receptors using muscarinic antagonists. This proposed pharmacological interaction is supported by clinical evidence which suggests that combinations of long-acting $\beta_{2}$-agonists (LABAs) and long-acting muscarinic antagonists (LAMAs) result in significantly greater improvements in lung function (forced expiratory volume in 1 second, $F E V_{1}$ ) than with individual components, ${ }^{5,6}$ and that such improvements are maintained in the long term. ${ }^{7.8}$

Although improving lung function is a key goal of COPD pharmacotherapy, $\mathrm{FEV}_{1}$ measurements alone may not adequately reflect the impact of a treatment on a patient, and improvements in patient-centred outcomes such as symptoms, dyspnoea, and health status may better reflect the effectiveness of a particular pharmacotherapy. ${ }^{9,10}$ Furthermore, alternative outcome measures may better reflect the overall clinical status of the patient, and may be more significant to patients day-to-day. ${ }^{11}$

\footnotetext{
* Corresponding author: Professor Thys van der Molen, Department of General Practice, University M edical Center Groningen, PO Box 196, Groningen 9700AD, The Netherlands. Tel: +31 503637478 E-mail: t.van.der.molen@med.umcg.nl
} 
Clinical investigations of LABA/LAMA combinations have included patient-centred outcomes as study endpoints; however, available study data have not been systematically evaluated by outcome. This review examines the clinical evidence published to date for the use of LABA/LAMA combinations in COPD, with a focus on outcomes beyond FEV 1 alone (see trial overview in Table 1). All trials administered tiotropium and indacaterol once daily and formoterol, arformoterol and salmeterol twice daily, unless otherwise stated.

\section{Table 1. Clinical trial characteristics: randomised studies of long-acting $\beta_{2}$-agonists combined with long-acting} muscarinic antagonists

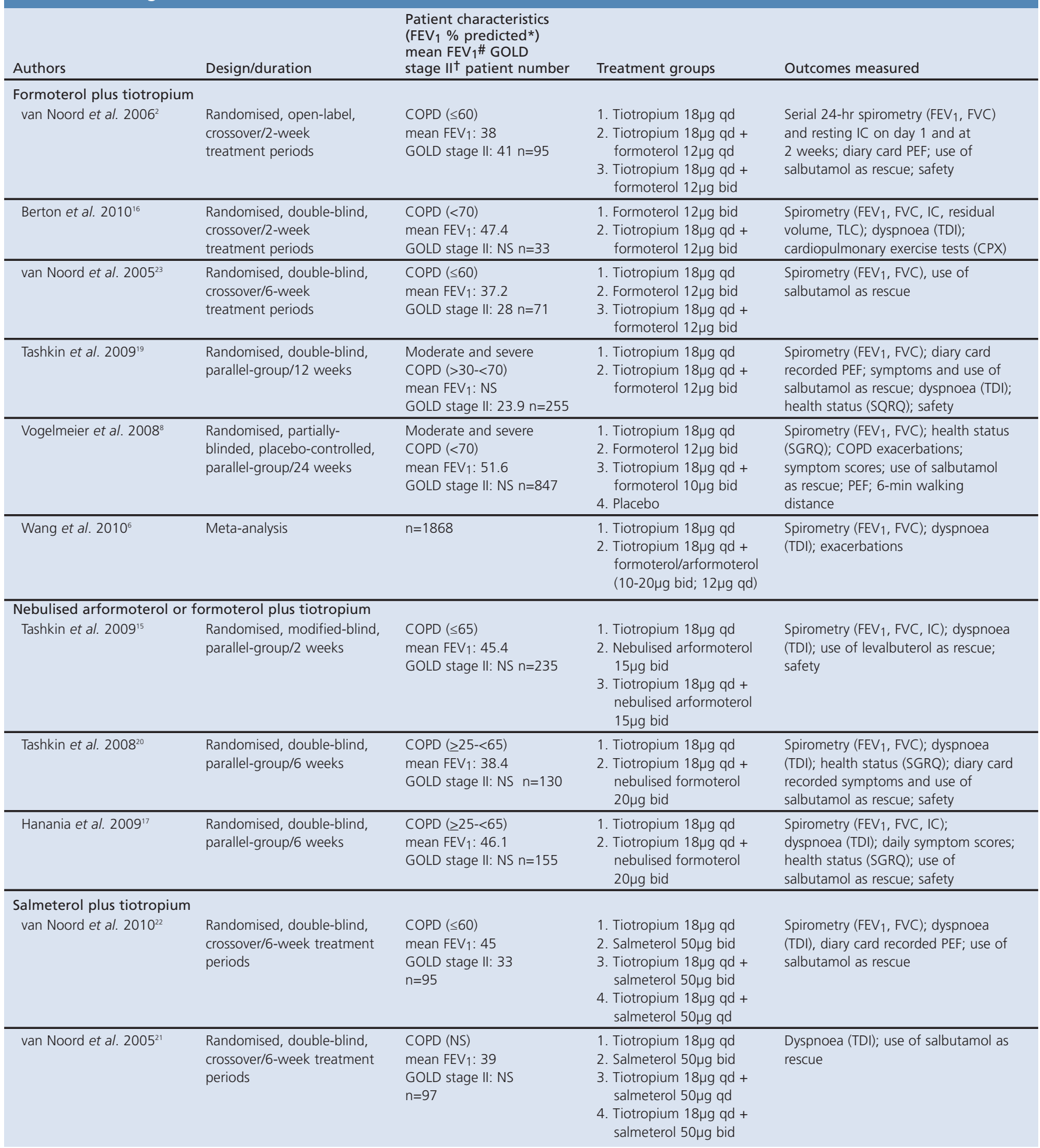




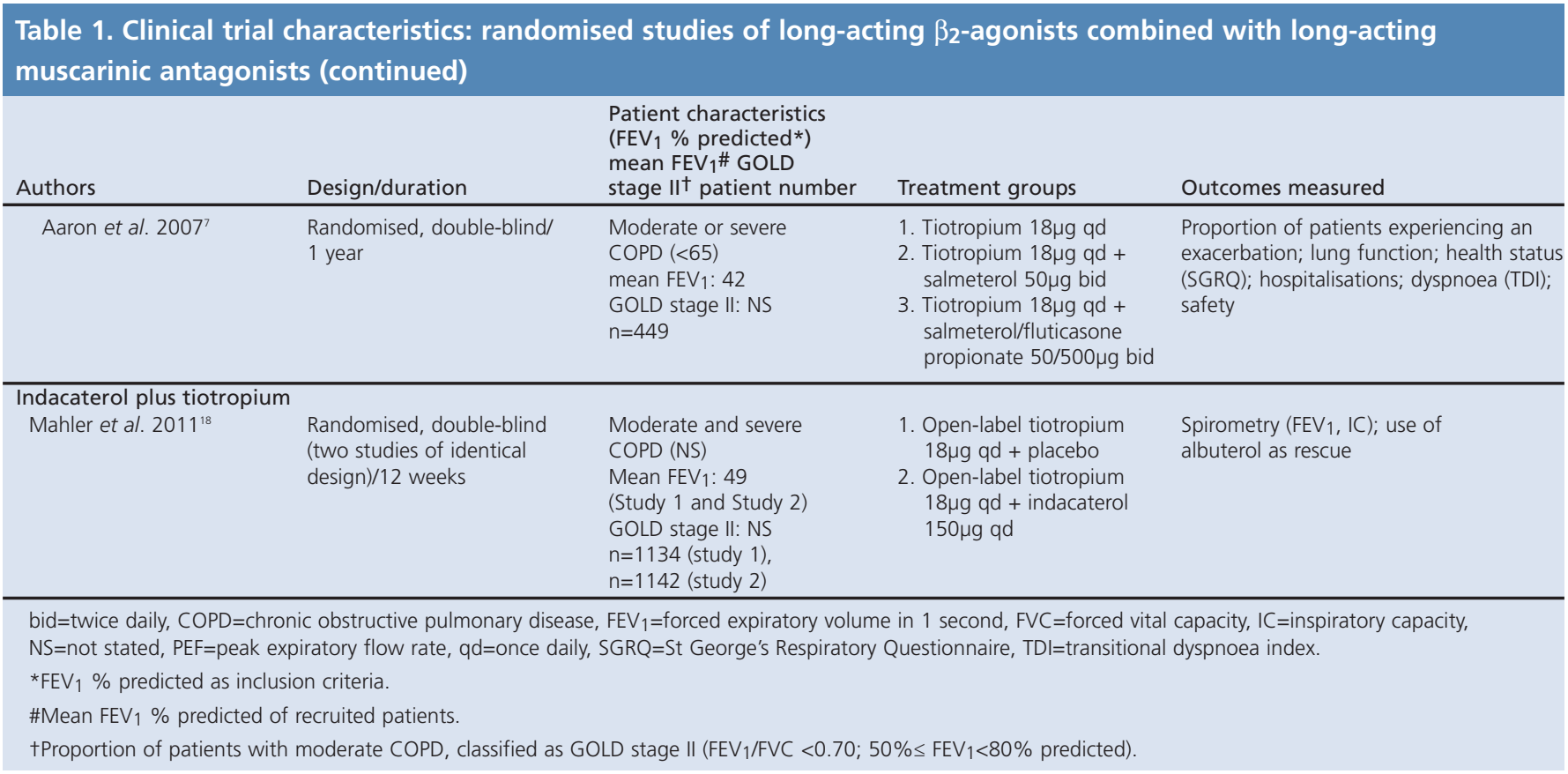

\section{Beyond spirometry: the effects of LABA/LAMA combination therapy Inspiratory capacity and reduction of hyperinflation}

In patients with COPD, delayed lung emptying can lead to an increase in end-expiratory lung volume (EELV) and consequently lung overinflation or 'hyperinflation'. Increases in EELV correlate with decreases in inspiratory capacity (IC) in COPD, and patients can experience respiratory discomfort. ${ }^{12-14}$ Therapies that improve IC (and reduce hyperinflation) may therefore help to lessen the respiratory discomfort experienced by patients with COPD.

There is limited clinical evidence for the effect of LABA/LAMA therapy on EELVIIC outcomes; however, treatment with tiotropium and formoterol/arformoterol combination has demonstrated efficacy over LABA monotherapy in three 2-week studies and one 6-week study. 2,15-17 In the first 2-week study, tiotropium with add-on formoterol once daily in the morning was shown to improve IC for $>12$ hrs compared with tiotropium alone, with further improvements in patients who received addon formoterol twice daily; however, the duration of improvement of IC was $<10$ hrs following the evening formoterol dose (Figure 1). ${ }^{2}$ There was no significant difference in trough IC response among the three treatment groups.

In the second 2-week study, nebulised arformoterol and tiotropium combination therapy provided a mean improvement from baseline in IC of $0.29 \pm 0.39 \mathrm{~L}$ compared with $0.20 \pm 0.32 \mathrm{~L}$ (arformoterol) and $0.19 \pm 0.32 \mathrm{~L}$ (tiotropium)..$^{15}$ The third 2-week study assessed the impact of tiotropium/formoterol combination therapy versus formoterol monotherapy on dynamic hyperinflation and exercise endurance in COPD patients. ${ }^{16} \mathrm{IC}$ was measured using constant-speed treadmill tests to the limit of tolerance (Tlim), or a maximum of 20 mins. Percentage improvement from baseline in Tlim was significantly greater after
Figure 1. Mean IC before (24-hr baseline) and at the end of 2-week treatment periods (means adjusted for period, centre, and patient within centre). ${ }^{2} * p<0.05$ tiotropium + formoterol twice daily (bid) vs. tiotropium; $p<0.05$ tiotropium + formoterol once daily (qd) vs. tiotropium; ${ }^{\dagger} p<0.05$ tiotropium + formoterol twice daily vs. tiotropium + formoterol once daily. IC=inspiratory capacity

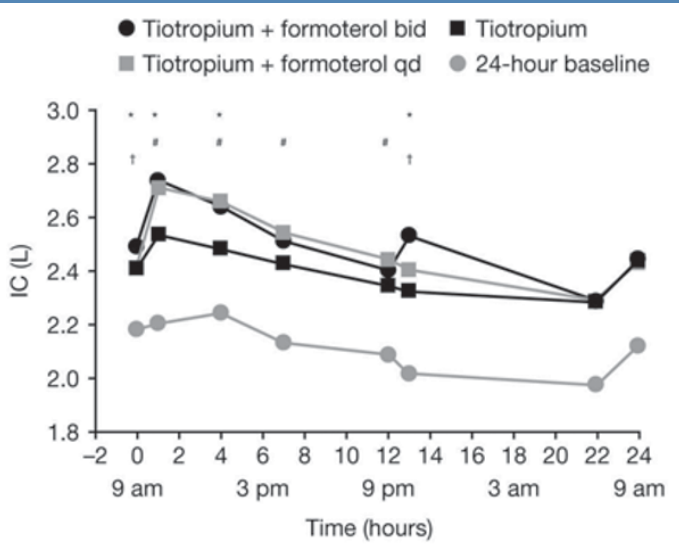

combination therapy than with formoterol alone $(124 \pm 27 \%$ vs. $68 \pm 14 \%, p<0.05)$. EELV was further reduced with the combination versus monotherapy $(p<0.05)$. In addition, a 6 week study demonstrated a significant improvement in postdose IC with nebulised formoterol plus tiotropium compared with tiotropium alone $(p<0.005$; peak IC improvement $230 \mathrm{~mL}$ with combination therapy at week 6 vs. monotherapy). ${ }^{17}$

Furthermore, two 12-week studies demonstrated the superior efficacy of tiotropium and indacaterol combination therapy over LAMA monotherapy. ${ }^{18}$ At week 12 , addition of indacaterol to tiotropium provided significantly greater increases in trough IC $(130 \mathrm{~mL}$ and $100 \mathrm{~mL}$ for studies 1 and 2, respectively) 
compared with tiotropium alone (both $p<0.01$ ). Clinical evidence thus indicates that LABA/LAMA combination therapy improves IC (and, used as a surrogate marker, can therefore be considered to reduce hyperinflation) in patients with COPD.

\section{Dyspnoea}

Dyspnoea is a common and troublesome manifestation of COPD and relief from dyspnoea is an important goal of pharmacotherapy. ${ }^{1}$ Studies of LABA/LAMA combination therapy that included dyspnoea as an endpoint are detailed in Table 2. All studies of tiotropium and formoterol/arformoterol combination therapy improved dyspnoea (assessed by the Transitional Dyspnoea Index (TDI)) to a greater extent than either monotherapy. ${ }^{6,15-17,19,20}$ Two further studies of tiotropium plus salmeterol (once or twice a day) also showed a marked improvement in dyspnoea with combination therapy over either monotherapy. ${ }^{21,22}$ In a study by Aaron et al., ${ }^{7}$ no significant difference in mean TDI total score was demonstrated between tiotropium plus salmeterol, tiotropium plus salmeterol/ fluticasone and tiotropium alone; however, it should be noted that a large number of patients discontinued during this study (61.0\% completed), making it difficult to draw firm conclusions on efficacy between treatment groups.

A greater proportion of patients achieved the minimum clinically important difference (MCID) in TDI total score of $\geq 1$ unit with combination therapies than with LABA or LAMA monotherapy. The proportion of patients achieving the MCID in TDI total score was 31.1-57.1\% for tiotropium monotherapy, $48.0-66.7 \%$ for LABA monotherapy, and $57.7-77.9 \%$ for LABA/LAMA combination therapy. 17,19,20,22

Overall, LABAILAMA combination therapy demonstrated clinically relevant improvements in dyspnoea, greater than those seen with LABA or tiotropium alone.

Table 2. Dyspnoea reported in long-acting $\beta_{2}$-agonist/long-acting muscarinic antagonist (LABA/LAMA) combination therapy clinical trials

\begin{tabular}{|c|c|c|c|c|}
\hline Authors & Duration & Mean BDI score & Mean TDI total score & $\begin{array}{l}\text { Patients achieving MCID (change } \geq 1 \\
\text { unit) in TDI total score, } \mathrm{n}(\%)\end{array}$ \\
\hline Berton et al. $2010^{16}$ & 2 weeks & $<9^{*}$ & $\begin{array}{l}\text { Formoterol: } 2.9 \\
\text { Tiotropium + formoterol: } 3.8(p=0.054 \\
\text { vs. formoterol) }\end{array}$ & - \\
\hline Tashkin et al. $2009^{15}$ & 2 weeks & $\begin{array}{l}\text { Nebulised arformoterol: } 5.8 \\
\text { Tiotropium: } 5.8 \\
\text { Tiotropium + nebulised arformoterol: } 5.5\end{array}$ & $\begin{array}{l}\text { Nebulised arformoterol: } 2.3 \\
\text { Tiotropium: } 1.8 \\
\text { Tiotropium + nebulised arformoterol: } 3.1\end{array}$ & $\begin{array}{l}\text { Nebulised arformoterol: } 50(66.7 \%) \\
\text { Tiotropium: } 44(57.1 \%) \\
\text { Tiotropium + nebulised arformoterol: } \\
60(77.9 \%) \text { (statistically significant vs. } \\
\text { tiotropium; } 95 \% \mathrm{Cl} 0.06,0.35)\end{array}$ \\
\hline Tashkin et al. $2008^{20}$ & 6 weeks & $\begin{array}{l}\text { Tiotropium: } 6.4 \\
\text { Tiotropium + nebulised arformoterol: } 6.3\end{array}$ & $\begin{array}{l}\text { Tiotropium: } 0.16 \\
\text { Tiotropium + nebulised arformoterol: } 2.3 \\
\text { (LS mean difference vs. tiotropium }=1.80 \text {; } \\
95 \% \mathrm{Cl}, 0.859 \text { to } 2.740, \mathrm{p}=0.0002 \text { ) }\end{array}$ & $\begin{array}{l}\text { Tiotropium: } 63(31.1 \%) \\
\text { Tiotropium + nebulised arformoterol: } 66 \\
(57.7 \%)\end{array}$ \\
\hline Hanania et al. $2009^{17}$ & 6 weeks & $\begin{array}{l}\text { Tiotropium: } 5.80 \\
\text { Tiotropium + formoterol: } 5.92\end{array}$ & $\begin{array}{l}\text { Tiotropium: } 0.87 \\
\text { Tiotropium + formoterol: } 1.59 \\
\text { (LS mean difference vs. tiotropium= } \\
0.72 ;-0.16 \text { to } 1.60, p=0.11 \text { ) }\end{array}$ & $\begin{array}{l}\text { Tiotropium: } 34(47.2 \%) \\
\text { Tiotropium + formoterol: } 45(58.4 \%)\end{array}$ \\
\hline van Noord et al. $2010^{22}$ & 6 weeks & 7.0 & $\begin{array}{l}\text { Tiotropium: } 1.18 \\
\text { Salmeterol bid: } 0.97 \\
\text { Tiotropium + salmeterol qd: } 2.56 \\
\text { Tiotropium + salmeterol bid: } 2.71 \\
\text { ( } p<0.005 \text { for tiotropium + salmeterol (qd } \\
\text { or bid) vs. either monotherapy) }\end{array}$ & $\begin{array}{l}\text { Salmeterol bid: } 95(48 \%) \\
\text { Tiotropium: } 95(57 \%) \\
\text { Tiotropium + salmeterol qd: } 95(67 \%) \\
\text { Tiotropium + salmeterol bid: } 95(72 \%)\end{array}$ \\
\hline van Noord et al. $2005^{21}$ & 6 weeks & 6.9 & $\begin{array}{l}\text { - } \\
\text { (tiotropium + salmeterol (bid or qd) } \\
\text { superior to either monotherapy in } \\
\text { perceived dyspnoea) }\end{array}$ & - \\
\hline Tashkin et al. $2009^{19}$ & 12 weeks & $\begin{array}{l}\text { Tiotropium: } 5.67 \\
\text { Tiotropium + formoterol: } 5.34\end{array}$ & $\begin{array}{l}\text { Tiotropium: } 1.53 \\
\text { Tiotropium + formoterol: } 1.60 \\
\text { (difference between treatments significant } \\
\text { only at week } 8 \text { ( } 1.86 \text { tiotropium + } \\
\text { formoterol vs. } 1.01 \text { tiotropium; } \\
95 \% \mathrm{Cl} 0.18 \text { to } 1.51 ; p=0.013 \text { ) }\end{array}$ & - \\
\hline Aaron et al. $2007^{7}$ & 1 year & $\begin{array}{l}\text { Tiotropium: } 6.3 \\
\text { Tiotropium + salmeterol: } 6.5 \\
\text { Tiotropium + salmeterol/fluticasone: } 6.5\end{array}$ & $\begin{array}{l}\text { Tiotropium: } 1.78 \\
\text { Tiotropium + salmeterol: } 1.40 \\
\text { Tiotropium + salmeterol/fluticasone: } 1.84 \\
\text { (no significant difference between } \\
\text { treatment groups) }\end{array}$ & - \\
\hline Wang et al. $2010^{6}$ & $\begin{array}{l}\text { Meta- } \\
\text { analysis }\end{array}$ & - & $\begin{array}{l}- \\
\text { Mean change in TDI greater with } \\
\text { tiotropium }+ \text { formoterol vs. tiotropium } \\
(p<0.0001)\end{array}$ & $\begin{array}{l}\text { - } \\
\text { Larger proportion of patients receiving } \\
\text { tiotropium + formoterol achieved } \\
\text { clinically significant change in TDI vs. } \\
\text { tiotropium }(p<0.0001)\end{array}$ \\
\hline
\end{tabular}

$\mathrm{BDI}=$ baseline dyspnoea index, bid=twice daily, MCID=minimum clinically important difference, qd=once daily, TDI=transitional dyspnoea index.

*Specified as inclusion criteria, value not stated. 


\section{Symptoms, symptom scores, and rescue medication use}

Several studies have assessed the impact of LABA/LAMA combination therapy on patient-reported respiratory symptoms, and on the use of rescue medication to relieve symptoms.

In a 6-week study, shortness of breath, chest tightness, nighttime awakenings, and total respiratory symptom scores all significantly improved with nebulised formoterol plus tiotropium compared with tiotropium alone. Cough scores also improved, but did not significantly differ between treatment groups. ${ }^{20}$ Another 6-week study found no difference in overall symptom scores following treatment with nebulised formoterol plus tiotropium or tiotropium monotherapy. ${ }^{17}$ In a 12-week study, a combination of formoterol and tiotropium significantly improved symptom scores from baseline to last study visit compared with tiotropium alone, although there was no difference between groups in the number of nocturnal awakenings..$^{19} \mathrm{~A}$ longer-term study (6 months) showed no difference in average daily symptom scores for patients receiving combination therapy (formoterol plus tiotropium) compared with those receiving bronchodilator monotherapy. ${ }^{8}$

Short-acting $\beta_{2}$-agonists (e.g. salbutamol/albuterol) are often used by COPD patients as rescue medication to help alleviate symptoms. Short-term ( $\leq 6$ weeks) and longer-term ( $\geq 12$ weeks) studies demonstrated a decrease in rescue medication use with tiotropium and LABA (formoterol/arformoterol/salmeterol) combination therapy compared with either monotherapy, which may be associated with the improvements in symptoms observed with LABA/LAMA combination therapies in these studies. 2,8,15,17,19-23 The reduction in rescue medication use in a 2-week and 6-week study of tiotropium plus formoterol compared with tiotropium is shown in Figure 2.,17 Two 12-week studies also demonstrated a numerically greater reduction in rescue medication use with tiotropium/indacaterol combination therapy compared with tiotropium alone. ${ }^{18}$

Overall, there was a trend for improvement in symptom scores and rescue medication use in favour of combination therapy compared with monotherapy.

\section{Exacerbations}

Prevention of exacerbations is one of the most important goals of COPD management. However, only a small number of LABA/LAMA combination studies have included exacerbations as an endpoint, and across these studies the definition of an exacerbation differs (or is not detailed), making it difficult to draw conclusions on efficacy (Table 3). Overall, no significant difference was demonstrated in the incidence of exacerbations or the time to first exacerbation between LABA/LAMA combination treatments and monotherapy. ${ }^{6-8,19}$ Further studies assessing the impact of combination bronchodilator therapy on COPD exacerbations are required.

\section{Health status}

As COPD progresses, the ability to function and perform activities on a daily basis reduces and, consequently, health status
Figure 2. Mean number of puffs of rescue medication (salbutamol) per day over (a) 2-week ${ }^{2}$ and (b) 6-w eek ${ }^{17}$ treatment periods. NS=not significant, SEM=standard error of mean. $* p<0.05$ vs. tiotropium

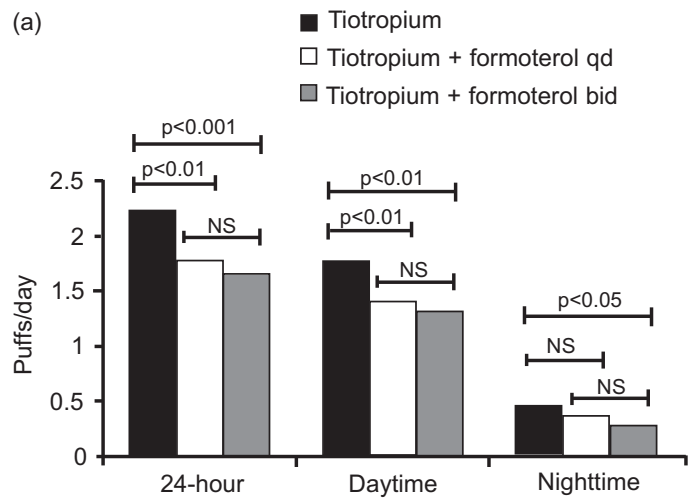

(b)

- Tiotropium + nebulised formoterol

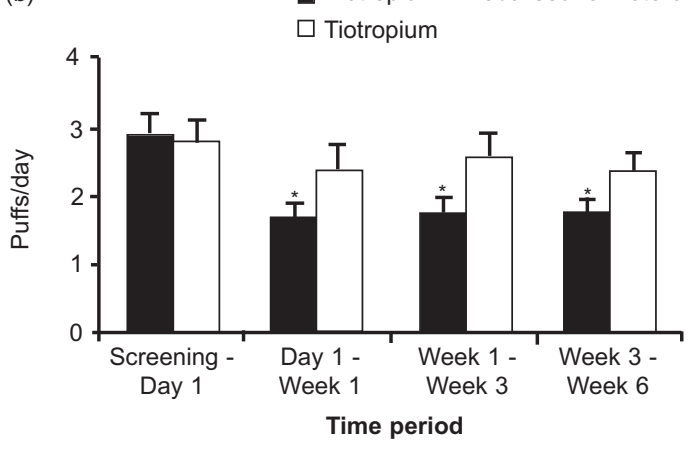

deteriorates. ${ }^{1,24}$ The St George's Respiratory Questionnaire (SGRQ) is a validated measure of health status that is frequently used in clinical trials. ${ }^{24}$ The MCID is defined as a decrease from baseline or placebo of $\geq 4$ points in the SGRQ total score.

A total of five studies have examined the effect of LABA/LAMA treatment on health status, and all used the SGRQ as the assessment tool. $78,17,19,20$ In longer-term studies $(\geq 12$ weeks), both LAMA (tiotropium) and LABA/LAMA combination therapies improved total SGRQ from baseline (Table 4). ${ }^{7,8,19}$ In two studies the improvement in SGRQ with tiotropium plus formoterol or tiotropium plus salmeterol was greater than with tiotropium alone, with the difference attaining statistical significance in one study. ${ }^{7} 19$ These two studies also reported the values for change in total SGRQ, indicating that the total scores were around the MCID for tiotropium (improvement of 3.8 and 4.5) and well above the MCID for tiotropium plus formoterol or salmeterol (4.81 and 6.3). ${ }^{7.19}$ These results indicate that the improvement in SGRQ total score was clinically significant with LABA/LAMA treatment. In a third long-term study, the improvements in SGRQ total score with tiotropium, formoterol, and tiotropium plus formoterol were significantly greater than with placebo, but did not show any significant difference between treatment groups. ${ }^{8}$ The lack of a consistent statistically significant difference in improvement in the SGRQ score between LAMA and LABA/LAMA treatment may be 
Table 3. Exacerbations reported in long-acting $\beta_{2}$-agonist/long-acting muscarinic antagonist (LABA/LAMA) combination therapy clinical trials

\begin{tabular}{|c|c|c|c|c|c|}
\hline Authors & Duration & Exacerbation definition & Incidence of & Mean duration of & Time to first \\
\hline & & & exacerbations, n (\%) & exacerbation & exacerbation (days) \\
\hline $\begin{array}{l}\text { Tashkin et al. } \\
2009^{19}\end{array}$ & 12 weeks & - & $\begin{array}{l}\text { Tiotropium: } 14(11 \%) \\
\text { Tiotropium + formoterol: } 21(17 \%) \\
\text { (no significant difference between } \\
\text { treatment groups; } \mathrm{p}=0.149 \text { ) }\end{array}$ & $\begin{array}{l}\text { Tiotropium: } 19.4 \text { days } \\
\text { Tiotropium + formoterol: } \\
16.2 \text { days }\end{array}$ & - \\
\hline $\begin{array}{l}\text { Vogelmeier et al. } \\
2008^{8}\end{array}$ & 24 weeks & $\begin{array}{l}\text { 'COPD exacerbation days' }= \\
\text { days with at least two symptoms } \\
(0-3 \text { scale of breathlessness, } \\
\text { cough, wheeze, amount } \\
\text { of sputum, colour of sputum) } \\
\text { recorded as being worse than } \\
\text { usual }\end{array}$ & $\begin{array}{l}\text { Tiotropium: } 23(10.4 \%) \\
\text { Formoterol: } 17(8.1 \%) \\
\text { Tiotropium + formoterol: } 13(6.3 \%) \\
\text { Placebo: } 30(14.4 \%)\end{array}$ & $\begin{array}{l}\text { Formoterol: } 2.4 \dagger \\
\text { Tiotropium: } 3.3+ \\
\text { Tiotropium + formoterol: } \\
3.3+\end{array}$ & - \\
\hline $\begin{array}{l}\text { Aaron et al. } \\
2007^{7}\end{array}$ & 1 year & $\begin{array}{l}\text { At least one exacerbation of } \\
\text { COPD requiring treatment with } \\
\text { systemic steroids or antibiotics } \\
\text { within the } 12 \text { months before } \\
\text { randomisation }\end{array}$ & $\begin{array}{l}\text { Tiotropium: } 98 \text { (62.8\%) } \\
\text { Tiotropium + salmeterol: } 96 \text { (64.8\%) } \\
\text { Tiotropium + salmeterol/fluticasone: } \\
87(60.0 \%) \\
\text { (no significant difference in absolute } \\
\text { risk reduction between either } \\
\text { combination therapy and tiotropium) }\end{array}$ & - & $\begin{array}{l}\text { Tiotropium: } 130 \\
\text { Tiotropium + salmeterol: } 128 \\
\text { Tiotropium + salmeterol/ } \\
\text { fluticasone: } 217 \text { (compared } \\
\text { with tiotropium, tiotropium + } \\
\text { fluticasone/salmeterol did not } \\
\text { statistically prolong time to } \\
\text { first exacerbation; adjusted } \\
\text { HR=0.80 (95\% CI0.60 to } \\
1.08, p=0.15)\end{array}$ \\
\hline $\begin{array}{l}\text { Wang et al. } \\
2010^{6}\end{array}$ & $\begin{array}{l}\text { Meta- } \\
\text { analysis }\end{array}$ & - & $\begin{array}{l}\text { Tiotropium: } 8.9 \% * \\
\text { Tiotropium + formoterol: } 8.3 \% \text { * } \\
\text { (no difference between treatment grou } \\
\mathrm{OR}=0.93,95 \% \mathrm{Cl} 0.45 \text { to } 1.93, \mathrm{p}=0.8\end{array}$ & $\begin{array}{l}- \\
\text { p) } \\
\text { s): }\end{array}$ & - \\
\hline
\end{tabular}

$\mathrm{HR}=$ hazard ratio, $\mathrm{OR}=\mathrm{odds}$ ratio. ${ }^{*}$ Overall cumulative incidence. $+\mathrm{COPD}$ exacerbation days (\% of treatment days).

because of the substantial improvement attained in both treatment groups, making differentiation between treatments difficult. Moreover, as assessment of health status was not the primary endpoint in these studies, it is unlikely the studies were sufficiently powered to show a difference in SGRQ total score between active treatments.

Two short-term studies (6 weeks) of tiotropium plus nebulised formoterol versus tiotropium monotherapy found no difference in SGRQ scores from baseline to week 6 or between treatments. ${ }^{17,20}$ This is perhaps not surprising given the short duration of the studies; the effect of treatment on health status may not be apparent after only 6 weeks of treatment.

The improvement in SGRQ total score with LABA/LAMA treatment appears to be driven by the effect on the symptom domain of the SGRQ rather than the domains of activity or impact. Indeed, several studies have shown an improvement in the symptom domain with LABA/LAMA treatment compared with LAMA monotherapy, which was statistically significant in two studies. $8,19,20$

The studies identified here all used the SGRQ to assess health status. This is a comprehensive questionnaire that takes time to complete and score, limiting its use in routine clinical practice. ${ }^{10}$

Table 4. Health status reported in long-acting $\beta_{2}$-agonist/long-acting muscarinic antagonist (LABA/LAMA) combination therapy clinical trials

\begin{tabular}{|c|c|c|c|}
\hline Authors & Duration & Total SGRQ score & SGRQ domain score \\
\hline $\begin{array}{l}\text { Tashkin et al. } \\
2008^{20}\end{array}$ & 6 weeks & $\begin{array}{l}\text { No significant difference between treatment groups } \\
\text { (tiotropium; tiotropium + nebulised formoterol) }\end{array}$ & $\begin{array}{l}\text { Symptom score: tiotropium: }+0.5 \text {; tiotropium + nebulised formoterol: } \\
-5.8(p=0.04,95 \% \mathrm{Cl},-12.2 \text { to }-0.35) \\
\text { No significant difference between treatment groups for activity or impact scores }\end{array}$ \\
\hline $\begin{array}{l}\text { Hanania et al. } \\
2009^{17}\end{array}$ & 6 weeks & - & $\begin{array}{l}\text { - } \\
\text { No significant difference between treatment groups } \\
\text { (tiotropium; tiotropium + nebulised formoterol) }\end{array}$ \\
\hline $\begin{array}{l}\text { Tashkin et al. } \\
2009^{19}\end{array}$ & 12 weeks & $\begin{array}{l}\text { Tiotropium: }-3.80 \\
\text { Tiotropium + formoterol: }-4.81 \\
\text { No significant difference between treatment groups }\end{array}$ & $\begin{array}{l}\text { Symptom score: tiotropium: }-3.97 \text {; tiotropium + formoterol: } \\
-8.33 \text { ( } p<0.05 \text { vs. tiotropium alone) } \\
\text { No significant difference between treatment groups for activity or impact scores }\end{array}$ \\
\hline $\begin{array}{l}\text { Vogelmeier et al. } \\
2008^{8}\end{array}$ & 24 weeks & $\begin{array}{l}\text { No significant difference between treatment groups } \\
\text { (tiotropium; formoterol; tiotropium + formoterol) }\end{array}$ & $\begin{array}{l}\text { - } \\
\text { Symptom score: significantly different from placebo for all treatment } \\
\text { groups (tiotropium; formoterol; tiotropium + formoterol) } \\
\text { No significant difference between treatment groups for activity or impact scores }\end{array}$ \\
\hline $\begin{array}{l}\text { Aaron et al. } \\
2007^{7}\end{array}$ & 1 year & $\begin{array}{l}\text { Tiotropium: }-4.5 \\
\text { Tiotropium + salmeterol: }-6.3 \text { ( } p=0.02 \text { vs. tiotropium) } \\
\text { Tiotropium + salmeterol/fluticasone: }-8.6 \\
\text { ( } p=0.01 \text { vs. tiotropium) }\end{array}$ & - \\
\hline
\end{tabular}


The effect of LABA/LAMA combination on health status measured with shorter questionnaires designed for use in clinical practice such as the Clinical COPD Questionnaire $(C C Q)^{25}$ and the COPD Assessment Test (CAT) ${ }^{26}$ are currently being investigated.

\section{Safety}

Any new LABA/LAMA combination must also take safety into consideration as additional efficacy or health status benefits must not be at the expense of safety. Several studies have shown no increase in frequency or severity of adverse events with tiotropium plus formoterol compared with tiotropium alone. $2.6,8,15,17,19,20,23$ The most common adverse event with both treatments was COPD exacerbation, and the combination was not associated with any clinically relevant changes in laboratory variables. $2,6,8,15,17,19,20,23$ Similar findings were recently reported in two large 12-week studies in which concurrent treatment with indacaterol and tiotropium did not increase the incidence of adverse events, serious adverse events, notable laboratory variables (plasma potassium and blood glucose), and ECG findings (QTc interval) compared with tiotropium alone. ${ }^{18}$ In another recent study, QVA149, a fixed-dose combination of indacaterol and a LAMA (NVA237), was well tolerated in patients with COPD, with a cardiovascular safety profile and overall adverse event rate similar to placebo. ${ }^{27}$

\section{LABA/LAMA combination therapy and the future of COPD management}

Current guidelines recommend the addition of a second bronchodilator to initial monotherapy in moderate COPD in order to maximise bronchodilation, ${ }^{1}$ and the impact of LABA/LAMA combinations on FEV 1 has been established. ${ }^{5}$ The studies detailed in this review indicate that LABA/LAMA combinations are also effective at improving patient-centred outcomes; however, additional studies assessing these outcomes are needed.

The trials considered here have reported on the free combination of a LABA (salmeterol or arformoterol/formoterol (once or twice a day) or indacaterol (once a day)) with tiotropium. Fixed-dose LABA/LAMA combinations are not currently available; however, the convenience of both agents in a single device may increase compliance and help to simplify COPD management further. It is likely that treatment options for COPD patients will expand further in the future to include free and fixed combinations of new LABAs or LAMAs (including once-daily fixed-dose combinations), which may lead to even greater improvements in patient-centred outcomes.

There are currently a number of LABA/LAMA fixed-dose combinations in development for COPD. ${ }^{28}$ QVA149 (an inhaled fixed-dose combination comprising two 24-hr agents, the LABA indacaterol and the LAMA NVA237) has demonstrated rapid and sustained bronchodilation with significant improvements compared with indacaterol monotherapy. ${ }^{29}$ Phase III trials in COPD to assess the long-term efficacy and safety of once-daily QVA149 are in progress. Initial studies with a once-daily fixeddose combination of the LABA olodaterol and tiotropium have also demonstrated superior bronchodilation in COPD compared with tiotropium alone. ${ }^{30}$ Other COPD treatment options in development include formoterol plus the LAMA aclidinium, and the LABA vilanterol plus the LAMA GSK-573719. ${ }^{31}$ Furthermore, novel compounds are being developed which act as dual antimuscarinic/ $\beta_{2}$-adrenergic receptor agonists (e.g. GSK961081 and PF-3429281). . $^{31,32}$

Despite the promising improvements in lung function demonstrated with current treatments, the question remains whether interventions that significantly improve $\mathrm{FEV}_{1}$ are also associated with improvements in other outcome measures. Several studies have demonstrated a significant relationship between poor lung function and a decline in health status in patients with COPD; ${ }^{33-38}$ however, there is limited evidence that changes in lung function associated with a therapeutic intervention correlate with changes in patient-centred outcomes. In a recent analysis, pooled data from three indacaterol studies $(12,26$, and 52 weeks in duration) were used to examine relationships between change from baseline of $\mathrm{FEV}_{1}$ and clinical outcomes (dyspnoea (TDI score), health status (SGRQ score) and exacerbations). ${ }^{39}$ The results of this analysis suggest that treatment interventions that significantly improve $\mathrm{FEV}_{1}$ are likely to be associated with greater improvements in patient-centred outcomes.

\section{Conclusions}

Studies of LABA/LAMA combinations to date indicate that combining different classes of bronchodilator results in significantly greater improvements in lung function and other meaningful outcomes such as IC, dyspnoea, symptom scores, rescue medication use, and health status compared with individual drugs. Additional studies assessing the impact of LABA/LAMA combination therapies on COPD exacerbations, using a standardised definition of an exacerbation, are clearly needed. Other elements of importance to patients such as exercise capacity, hospitalisations, depression, and pain are likely to be explored.

Bronchodilators remain central to the symptomatic management of COPD and as such, LABA/LAMA combination therapy could play an important role in maximising bronchodilation and improving IC, symptoms, health status and dyspnoea in patients with COPD. The last item is particularly important in those patients with moderate-to-severe disease, whose dyspnoea during daily activities is not relieved by shortacting bronchodilators and who require more effective LABA, LAMA, and combination treatments. The value of $\mathrm{FEV}_{1}$ alone as a surrogate marker of COPD is limited, and patient-centred outcomes are important for both adequate recognition of the disease and effective treatment of patients. Importantly, guidelines also now recognise the significance of such patientcentred outcomes in clinical trials of COPD therapies, with a view that they will better reflect the overall well-being of the patient, beyond lung function measurements alone. 


\section{Handling editor Irem Patel}

Acknowledgements Helen Attisha (ACUM ED) assisted in the preparation of the first draft of the manuscript, and also co-ordinated the authors' input into this and subsequent drafts. Mark Fedele (Novartis) critically reviewed the manuscript drafts. Neither fulfil the three ICMJE criteria for authorship, but we are very grateful indeed for their assistance.

Conflicta of interest TvdM has received research grants from AstraZeneca (AZ), GlaxoSmithKline (GSK), Nycomed, and MSD; consultancy fees from AZ, Nycomed, MSD, and Novartis; and speaker fees from AZ, GSK, Nycomed and MSD. MC has received honoraria for speaking and consulting and/or financial support for attending meetings from Abbott, AZ, Boehringer Ingelheim, Chiesi Farmaceutici, Dey, Gentili, GSK, Lallemand, Menarini Farmaceutici, Mundipharma, Novartis, Nycomed, Pfizer, Sanovel, Sigma Tau, and Valeas.

Contributorship The authors, Thys van der Molen and Mario Cazzola, were both involved in the concept and design of this article and the interpretation of the data. Both authors revised the article critically for important intellectual content, and gave their final approval of the version to be published.

Funding This study was funded by Novartis Pharma AG, Basel, Switzerland; development of this manuscript was also supported by Novartis.

\section{References}

1. GOLD. Global Strategy for the Diagnosis, Management and Prevention of Chronic Obstructive Pulmonary Disease. 2009.

2. van Noord JA, Aumann JL, Janssens $E$, et al. Effects of tiotropium with and without formoterol on airflow obstruction and resting hyperinflation in patients with COPD. Chest 2006;129(3):509-17. http://dx.doi.org/10.1378/chest.129.3.509

3. Cazzola M, Matera MG. Long-acting bronchodilators are the first-choice option for the treatment of stable COPD. Chest 2004;125(1):9-11 http://dx.doi.org/10.1378/chest.125.1.9

4. Hanania NA, Donohue JF. Pharmacologic interventions in chronic obstructive pulmonary disease: bronchodilators. Proc Am Thorac Soc 2007;4(7):526-34 http://dx.doi.org/10.1513/pats.200701-016FM

5. Cazzola M, Molimard $M$. The scientific rationale for combining long-acting beta2agonists and muscarinic antagonists in COPD. Pulm Pharmacol Ther 2010;23(4):25767. http://dx.doi.org/10.1016/j.pupt.2010.03.003

6. Wang J, Jin D, Zuo P, et al. Comparison of tiotropium plus formoterol to tiotropium alone in stable chronic obstructive pulmonary disease: a meta-analysis. Respirology 2010;16(2):350-8. http://dx.doi.org/10.1111/j.1440-1843.2010.01912.x

7. Aaron SD, Vandemheen $\mathrm{KL}$, Fergusson $\mathrm{D}$, et al. Tiotropium in combination with placebo, salmeterol, or fluticasone-salmeterol for treatment of chronic obstructive pulmonary disease: a randomized trial. Ann Intern Med 2007;146(8):545-55.

8. Vogelmeier $\mathrm{C}$, Kardos $\mathrm{P}$, Harari S, et al. Formoterol mono- and combination therapy with tiotropium in patients with COPD: a 6-month study. Respir Med 2008;102(11):1511-20. http://dx.doi.org/10.1016/j.rmed.2008.07.020

9. Jones PW, Agusti AG. Outcomes and markers in the assessment of chronic obstructive pulmonary disease. Eur Respir J 2006;27(4):822-32. http://dx.doi.org/10.1183/?09031936.06.00145104

10. Cazzola M, MacNee W, Martinez FJ, et al. Outcomes for COPD pharmacological trials: from lung function to biomarkers. Eur Respir J 2008;31(2):416-69. http://dx.doi.org/10.1183/?09031936.00099306

11. Jones PW, Kaplan RM. Methodological issues in evaluating measures of health as outcomes for COPD. Eur Respir J Suppl 2003;41:13-8s. http://dx.doi.org/10.1183/?09031936.03.00077803

12. Calverley PM. Dynamic hyperinflation: is it worth measuring? Proc Am Thorac Soc 2006;3(3):239-44. http://dx.doi.org/10.1513/pats.200508-084SF

13. Duranti R, Filippelli $M$, Bianchi $R$, et al. Inspiratory capacity and decrease in lung hyperinflation with albuterol in COPD. Chest 2002;122(6):2009-14. http://dx.doi.org/10.1378/chest.122.6.2009

14. Stubbing DG, Pengelly LD, Morse JL, Jones NL. Pulmonary mechanics during exercise in subjects with chronic airflow obstruction. J Appl Physiol 1980;49(3):511-5.

15. Tashkin DP, Donohue JF, Mahler DA, et al. Effects of arformoterol twice daily, tiotropium once daily, and their combination in patients with COPD. Respir Med 2009;103(4):516-24. http://dx.doi.org/10.1016/j.rmed.2008.12.014

16. Berton DC, Reis $M$, Siqueira $A C$, et al. Effects of tiotropium and formoterol on dynamic hyperinflation and exercise endurance in COPD. Respir Med 2010;104(9):1288-96. http://dx.doi.org/10.1016/j.rmed.2010.05.017
17. Hanania NA, Boota A, Kerwin E, Tomlinson L, is-Mize K. Efficacy and safety of nebulized formoterol as add-on therapy in COPD patients receiving maintenance tiotropium bromide: results from a 6-week, randomized, placebo-controlled, clinical trial. Drugs 2009;69(9):1205-16. http://dx.doi.org/10.2165/00003495-200969090-00005

18. Mahler DA, D'Urzo A, Peckitt $C$, et al. Combining once-daily bronchodilators in COPD: indacaterol plus tiotropium versus tiotropium alone. Am J Respir Crit Care Med 2011;183:A1591

19. Tashkin DP, Pearle J, lezzoni D, Varghese ST. Formoterol and tiotropium compared with tiotropium alone for treatment of COPD. COPD 2009;6(1):17-25. http://dx.doi.org/10.1080/15412550902724073

20. Tashkin DP, Littner $M$, Andrews $C P$, et al. Concomitant treatment with nebulized formoterol and tiotropium in subjects with COPD: a placebo-controlled trial. Respir Med 2008;102(4):479-87. http://dx.doi.org/10.1016/j.rmed.2007.12.019

21. van Noord J, Aumann L, Janssens E, et al. Combination therapy of tiotropium plus salmeterol superior to single agent therapy in terms of dyspnea improvement in COPD (abstract). Chest 2005;128:177S

22. van Noord JA, Aumann JL, Janssens E, et al. Combining tiotropium and salmeterol in COPD: Effects on airflow obstruction and symptoms. Respir Med 2010;104(7):9951004. http://dx.doi.org/10.1016/j.rmed.2010.02.017

23. van Noord JA, Aumann JL, Janssens $E$, et al. Comparison of tiotropium once daily, formoterol twice daily and both combined once daily in patients with COPD. Eur Respir J 2005;26(2):214-22. http://dx.doi.org/10.1183/?09031936.05.00140404

24. Jones PW, Quirk FH, Baveystock CM, Littlejohns P. A self-complete measure of health status for chronic airflow limitation. The St George's Respiratory Questionnaire. Am Rev Respir Dis 1992;145(6):1321-7.

25. van der Molen T, Willemse BW, Schokker S, et al. Development, validity and responsiveness of the Clinical COPD Questionnaire. Health Qual Life Outcomes 2003;1:13. http://dx.doi.org/10.1186/1477-7525-1-13

26. Jones PW, Harding G, Berry P, et al. Development and first validation of the COPD Assessment Test. Eur Respir J 2009;34(3):648-54. http://dx.doi.org/10.1183/09031936.00102509

27. Van de Maele B, Fabbri LM, Martin C, et al. Cardiovascular safety of QVA149, a combination of indacaterol and NVA237, in COPD patients. COPD 2010;7(6):418-27. http://dx.doi.org/10.3109/15412555.2010.528812

28. Cazzola M, Matera MG. Emerging inhaled bronchodilators: an update. Eur Respir J 2009;34(3):757-69. http://dx.doi.org/10.1183/?09031936.00013109

29. van Noord JA, Buhl R, Laforce C, et al. QVA149 demonstrates superior bronchodilation compared with indacaterol or placebo in patients with chronic obstructive pulmonary disease. Thorax 2010;65(12):1086-91. http://dx.doi.org/10.1136/thx.2010.139113

30. Maltais $F$, Beck $E$, Webster $D$, et al. Four weeks once daily treatment with tiotropium+olodaterol (BI 1744) fixed dose combination compared with tiotropium in COPD patients (abstract). Eur Respir J 2010;36:5557

31. Clinicaltrials.gov. www.clinicaltrials.gov 2011.

32. Philip J, Gray A, Clarke N, Yeadon M, Perros-Huguet C. Demonstration of dual pharmacology in vivo of PF-3429281: a novel inhaled dual antimuscarinic/ß2 agonist (abstract). Eur Respir J 2010;36:1231

33. Anzueto A, Leimer I, Kesten S. Impact of frequency of COPD exacerbations on pulmonary function, health status and clinical outcomes. Int J Chron Obstruct Pulmon Dis 2009;4:245-51. http://dx.doi.org/10.2147/COPD.S4862

34. Camargo CA Jr, Tsai CL, Clark S, Kenney PA, Radeos MS. Spirometric correlates of dyspnea improvement among emergency department patients with chronic obstructive pulmonary disease exacerbation. Respir Care 2008;53(7):892-6.

35. Niewoehner DE. Relation of chronic obstructive pulmonary disease exacerbations to FEV(1)--an intricate tango. Respiration 2009;77(2):229-35. http://dx.doi.org/10.1159/000162877

36. Watson L, Schouten JP, Lofdahl CG, et al. Predictors of COPD symptoms: does the sex of the patient matter? Eur Respir I 2006;28(2):311-18. http://dx.doi.org/10.1183/?09031936.06.00055805

37. Mannino DM, Davis KJ. Lung function decline and outcomes in an elderly population Thorax 2006;61(6):472-7. http://dx.doi.org/10.1136/thx.2005.052449

38. McGlone S, Venn A, Walters EH, Wood-Baker R. Physical activity, spirometry and quality-of-life in chronic obstructive pulmonary disease. COPD 2006;3(2):83-8. http://dx.doi.org/10.1080/15412550600651263

39. Jones PW, Donohue J, Nedelman J, Pinault G, Pascoe S. Correlating changes in lung function with patient reported outcomes in COPD (abstract). Thorax 2010; 65:A141. http://dx.doi.org/10.1136/thx.2010.150987.49 